\title{
AWAITING INDUSTRY 4.0: TRANSFORMATION OF TERTIARY EDUCATION IN THE BALTIC COUNTRIES AND FINLAND
}

\author{
Edmunds Jansons, Baiba Rivza \\ Latvia University of Life Sciences and Technologies, Latvia \\ edmundjanson@gmail.com
}

\begin{abstract}
Baltic States and Finland are vibrant regions with similar sized population and historical experience. Their adaptation to the new digital era is undermined by lack of professionals. Across the EU a major reason for labour shortage in science, technology, engineering and mathematics (STEM) fields professionals lies in the insufficient supply of higher education graduates due to stagnant enrolment rates in STEM fields. The aim of this research addresses the existing trends in tertiary STEM education in Finland, Estonia, Latvia and Lithuania. This includes the tasks of analysing the quantitative trends (enrolment and graduation) in the HEIs of Baltics and Finland over the period from 2013 to 2017 as well as analysing the structural changes taking place in the respective higher education systems from 2013 to 2018. The Baltic States combined have numerical advantages in terms of young people, and young professionals (25-34 year olds) with tertiary education. However, in terms of the number of students and graduates Finland is at the forefront. The largest proportion of students enrolling in STEM fields lie within Finland (33.9\%) whereas the smallest one is in Latvia $(24.0 \%)$. Finland is also a leader in the share and total number of information and communication technology (ICT) graduates. In the period 2013-2017 Latvia's results improved in two $\left(5^{\text {th }}\right.$ and $\left.6^{\text {th }}\right)$ of the STEM study fields, Lithuania made a remarkable result in one STEM $\left(6^{\text {th }}\right)$ field by $46.9 \%$, Estonia saw a relative increase in the $5^{\text {th }}$ and $6^{\text {th }}$ study field while Finland experienced a numerical decrease in all three STEM fields.
\end{abstract}

Key words: higher education, regional disparity, integrated development.

\section{Introduction}

The advances in computer technologies and machine learning capabilities in the industry have led to a shift in labour market needs and further increased the need for STEM capable professionals. STEM study fields are Natural sciences, mathematics and statistics ( $5^{\text {th }}$ field), Information and Communication Technologies ( $6^{\text {th }}$ field $)$, Engineering, manufacturing and construction ( $7^{\text {th }}$ field) (UNESCO, 2015). They are seen as especially important for fostering innovation and economic growth. Many countries try to increase the rate of students taking up STEM education, or to attract highly qualified immigrants with degrees of given field. In OECD countries among tertiaryeducated adults, in 2016 an average of $25 \%$ had been studying STEM fields (OECD, 2017a).

The term 'Industry 4.0 ' revolution' standing for 'Digitalization of Industry' has first been used in 2011 by the German Ministry of Education and Research (Bundesministerium für Bildung und Forschung) in their high-tech strategy 'Zukunftsprojekte der Hightech-Strategie (HTSAktionsplan)' describing the industry based on Cyber Physical Systems (BMBF, 2019). The Industry 4.0 integrates cyber-physical systems and the Internet of Things (IoT), big data and cloud computing, robotics, artificial-intelligence systems and additive manufacturing and is expected to evolve in an exponential rather than at a linear pace (European Union, 2017).

There is an understanding that the higher education is a fundamentally important prerequisite to help society to adapt to the changing environment and allow individuals to increase their competitiveness in the changing labour market (Knight, 2012). According to the UK Government Office for Science, for countries in order to succeed in the new age of industry both the technological expertise and professional skills have to be prepared ahead of time. Likewise, the volume and detail of data captured by businesses in presence of the IoT will further increase, which in turn will allow companies both to become more efficient and better understand their customers as well as personalise products. For these reasons the popularity of STEM study subjects has to be increased. (Foresight, 2013). Also, the European Commission stresses the need for the education to tandem with the technology development, in order to avoid the deepening of the digital divide which could cause subsequent erosion of the social capital base (European Union, 2017). Across the EU, a major reason for the shortage of both Information, communications and technologies (ICT) and other Science, technology, engineering and mathematics (STEM) professionals lies in the insufficient supply of graduates from higher education to meet the increasing demand. Too few young people are enrolling to study STEM subjects at higher education. In order to tackle the shortage of STEM graduates, the EU Member states are using various measures incl. supply stimulus: investing in education and training; using reserves of labour and skills; reskilling employees. Some countries have developed national strategies to encourage people to study and work in STEM, ICT and R\&D i.e. research and development (CEDEFOP, 2016).

As mentioned by the European Centre for the Development of Vocational Training (CEDEFOP) the goals of Baltic States and Finland in the new digital 
era are hindered by the ageing population and lack of professionals (CEDEFOP, 2016) who are needed to succeed in the Industry 4.0. In terms of this research, the Baltic States are viewed both as independent countries and as a region and is compared with Finland - a developed country in economical as well as R\&D and education terms (OECD, 2017b) - the country which has long been a role model for the Baltic countries in different fields, most notably the education.

Aim of the research: Investigate the higher education tendencies in the Baltic countries and Finland in terms of quantitative and structural developments in the corresponding higher education institutions (HEIs) as a reflection of the changing future industry needs.

Tasks:

1. carry out analysis of the quantitative (number of students overall and by study fields) trends in the HEIs of Lithuania, Latvia, Estonia (Baltics) and Finland over the period from 2013 to 2017;

2 . investigate the structural changes taking place in the higher education systems in Lithuania, Latvia, Estonia and Finland over the period from 2013 to 2018 .

\section{Materials and Methods}

Research methods: scientific research, comparable analysis, descriptive statistics.

Research sources and materials: research is based on statistical data from the EUROSTAT, OECD, documents, research from various scientific sources of institutional background focused on the period from 2013 to 2018 . The research has been carried out in the spring of 2019.
Research limitations: the research focuses on the period since 2013, due to data availability and comparison related reasons. The type of tertiary institutions (public or private) as well as the citizenship of the students was not taken into account in this analysis due to data detail level limitations. Thus all students included in the statistics of a given country are treated as local students.

Research approach

The research includes analysis of information on the enrolled students and graduates according to their field of studies in the STEM fields of higher education systems in the Baltic countries and Finland. The basis for the research is comparable datasets on tertiary education systems therein (Eurostat, 2019). The summarized statistics include summary indicators on both the part-time and full-time International Standard Classification of Education (ISCED) $5^{\text {th }}, 6^{\text {th }}, 7^{\text {th }}, 8^{\text {th }}$ level students. The approach on the research on the higher education institutions has changed significantly over time. Authors underline some topicalities: (1) the mission of HEIs as a driving force of entrepreneurship thus increasing the overall prosperity (RadingerPeer \& Pflitsch, 2017); (2) the role of HEIs in the commercialization of knowledge (Goldstein \& Rehbogen, 2013); (3) the role of HEIs in ensuring of regional sustainability (Goldstein, 2010).

\section{Results and Discussion}

As of 2018 the population of Finland (FI) was 5513130 people, of Estonia (EE) - 1319 133, of Latvia (LV) - 1934 379, and of Lithuania (LT) -2 808901 people. In the Baltic States, there were altogether 6062413 people - almost 10\% more

Total number of students studying in tertiary education, graduates ISCED 6-8

Table 1

\begin{tabular}{|c|c|c|c|c|c|c|c|}
\hline \multirow{2}{*}{\multicolumn{2}{|c|}{$\begin{array}{c}\text { Country } \\
\text { students (stud.) } \\
\text { /graduates (grad.) }\end{array}$}} & \multicolumn{5}{|c|}{ Year } & \multirow{3}{*}{$\begin{array}{c}\text { Change in period } \\
\text { 2013-2017 (\%) } \\
-\end{array}$} \\
\hline & & \multirow{2}{*}{$\frac{2013}{19617528}$} & \multirow{2}{*}{$\begin{array}{c}2014 \\
19532167 \\
\end{array}$} & \multirow{2}{*}{$\begin{array}{c}2015 \\
18385922 \\
\end{array}$} & \multirow{2}{*}{$\begin{array}{c}2016 \\
19589999 \\
\end{array}$} & \multirow{2}{*}{$\frac{2017}{-}$} & \\
\hline & stud. & & & & & & \\
\hline$E U-28^{*}$ & grad. & - & 4752477 & 4609701 & 4473830 & - & - \\
\hline \multirow{2}{*}{$\mathrm{EE}$} & stud. & 64806 & 59998 & 55214 & 51092 & 47794 & -26.3 \\
\hline & grad. & 10867 & 10190 & 10491 & 10262 & - & $-6.6($ till 2016) \\
\hline \multirow{2}{*}{ LV } & stud. & $\begin{array}{c}94474 \\
(77126)^{*} \\
\end{array}$ & $\begin{array}{c}89671 \\
(72618)^{*} \\
\end{array}$ & $\begin{array}{c}85881 \\
(69776)^{*} \\
\end{array}$ & $\begin{array}{c}84282 \\
(69089)^{*}\end{array}$ & $\begin{array}{c}82914 \\
(68325)^{*} \\
\end{array}$ & $\begin{array}{c}-12.2 \\
(-11.4)^{*} \\
\end{array}$ \\
\hline & grad. & $\begin{array}{c}21610 \\
(17416)^{*}\end{array}$ & $\begin{array}{c}17345 \\
(13820)^{*} \\
\end{array}$ & $\begin{array}{c}17021 \\
(13236)^{*} \\
\end{array}$ & $\begin{array}{c}15796 \\
(12320)^{*} \\
\end{array}$ & $\begin{array}{c}14587 \\
(11727)^{*} \\
\end{array}$ & $\begin{array}{c}-32.5 \\
(-32.7)^{*}\end{array}$ \\
\hline \multirow{2}{*}{ LT } & stud. & 159695 & 148389 & 140629 & 133759 & 125863 & -21.2 \\
\hline & grad. & 39265 & 33130 & 32205 & 29683 & - & -24.4 (till 2016) \\
\hline \multirow{2}{*}{ FI } & stud. & 309009 & 306080 & 302478 & 297163 & - & -3.8 (till 2016) \\
\hline & grad. & 52730 & 53878 & 56829 & 56066 & 56136 & -6.5 \\
\hline
\end{tabular}

* study fields ISCED 5-8

Source: authors' calculations based on Eurostat, 2019. 
Proportion of students in ISCED 5-8 study field

Table 2

\begin{tabular}{|c|c|c|c|c|c|c|c|c|}
\hline \multirow{3}{*}{ 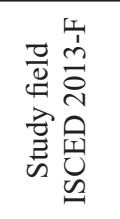 } & \multirow{3}{*}{$\begin{array}{l}\frac{\theta}{8} \\
0 \\
己 \\
\Xi \\
0 \\
0\end{array}$} & \multicolumn{3}{|c|}{ ISCED 6} & \multicolumn{4}{|c|}{ ISCED 6-8 } \\
\hline & & \multicolumn{2}{|c|}{ Proportion (\%) } & \multirow{2}{*}{$\begin{array}{c}\bar{x} \\
(\%)\end{array}$} & \multicolumn{2}{|c|}{ Proportion (\%) } & \multirow{2}{*}{$\begin{array}{l}\bar{x} \\
(\%)\end{array}$} & \multirow{2}{*}{$\begin{array}{c}\text { Numerical } \\
\text { change } \\
\text { in the period } \\
(\%)\end{array}$} \\
\hline & & 2013 & 2017 & & 2013 & 2017 & & \\
\hline \multirow{5}{*}{ 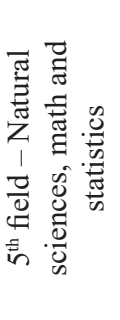 } & EU-28** & 8.2 (in 2014) & 8.8 (in 2016) & 8.6 & - & 7.9 (in 2016) & - & - \\
\hline & $\mathrm{EE}$ & 4.2 & 5.0 & 5.0 & 5.1 & 6.1 & 6.1 & -11.8 \\
\hline & LV & 2.0 & 3.0 & 2.8 & $2.7(2.2)^{*}$ & $3.3(2.8)^{*}$ & $3.3(2.8)^{*}$ & $10.8(11.3)^{*}$ \\
\hline & LT & 3.1 & 3.4 & 3.3 & 3.4 & 3.8 & 3.6 & -11.0 \\
\hline & $\mathrm{FI} * * *$ & 5.4 & 5.0 (in 2016) & 5.3 & 5.8 & 5.6 (in 2016) & 5.7 & -7.1 \\
\hline \multirow{5}{*}{ 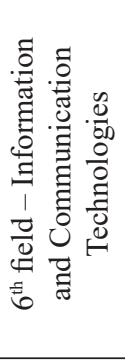 } & EU-28** & 4.5 (in 2014) & 4.8 (in 2016) & 4.8 & - & 4.1 (in 2016) & - & - \\
\hline & EE & 8.6 & 9.8 & 9.1 & 7.6 & 8.7 & 8.0 & -15.9 \\
\hline & LV & 4.4 & 6.8 & 6.0 & $4.8(4.6)^{*}$ & $6.5(6.2)^{*}$ & $5.7(5.5)^{*}$ & $12.5(18.8)^{*}$ \\
\hline & LT & 2.4 & 4.8 & 3.2 & 2.2 & 4.1 & 2.9 & 46.9 \\
\hline & $\mathrm{FI}^{* * *}$ & 9.6 & $\begin{array}{c}9.5 \\
\text { (in 2016) } \\
\end{array}$ & 9.4 & 9.2 & 9.1 & 9.1 & -5.0 \\
\hline \multirow{5}{*}{ 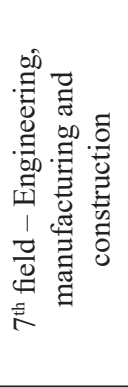 } & EU-28** & $\begin{array}{c}16.5 \\
\text { (in 2014) }\end{array}$ & $\begin{array}{c}15.1 \\
\text { (in 2016) }\end{array}$ & 15.7 & - & $\begin{array}{c}15.4 \\
\text { (in 2016) }\end{array}$ & - & - \\
\hline & EE & 15.2 & 15.0 & 15.5 & 16.8 & 16.3 & 16.8 & $-28,3$ \\
\hline & LV & 15.9 & 18.7 & 18.0 & $16.3(15.6)$ & $\begin{array}{c}16.8 \\
(16.6) \\
\end{array}$ & $\begin{array}{c}16.4 \\
(15.7) \\
\end{array}$ & $\begin{array}{c}-9.7 \\
(-6.8)^{*}\end{array}$ \\
\hline & LT & 20.0 & 21.7 & 20.7 & 18.0 & 19.4 & 18.3 & -15.1 \\
\hline & $\mathrm{FI}^{* * *}$ & 20.6 & $\begin{array}{c}20.1 \\
\text { (in 2016) }\end{array}$ & 20.6 & 19.2 & 18.8 & 19.1 & -5.5 \\
\hline
\end{tabular}

* Tertiary education data (ISCED levels 5-8)

** Tertiary education data (ISCED levels 5-8) available only for 2016, ISCED 5 for period 2014-2016

*** Tertiary education data (ISCED levels 6-8) available for period 2013-2016, ISCED 6 for period 2013-2016

Source: author's calculations based on Eurostat (2019).

than in Finland. When analysing the so called young adults' (aged 18 to 34) cohort, Finland had 1154564 young adults, Estonia - 280786 , Latvia - 397 872, Lithuania - 599 053, while Baltic States combined had - 1277711 young adults - by $10.7 \%$ more than Finland (Eurostat, 2018).

Thus, in regional terms, the Baltic States have a combined advantage in the number of young people. In terms of education in 2017, Finland had $41.3 \%$ young people with tertiary education (age group 25-34 years), Estonia - 43.0\%, Latvia - 41.6\%, Lithuania $55.6 \%$. Meanwhile, in the age group of 55-64 year-olds with tertiary education Finland had 38.5\%, Estonia $-36.4 \%$, Latvia - 27.1\%, Lithuania - 29.5\% (OECD, 2017c). Thus, in the last 30 years an increase can be seen in the overall tertiary education attendance in the Baltic countries, especially in Latvia and Lithuania.
It should be noted that only in Latvia there are shortterm tertiary (ISCED 5) study programmes (including STEM field).

Substantial differences can be noticed in terms of the number of enrolled students and graduates inbetween Finland and the Baltic States (Table 1).

On an ISCED 5-8 scale Estonia had 51092 enrolled students and 10262 graduates, Latvia - 84282 (excl. ISCED 5 - 69089) students and 15796 (excluding ISCED 5 - 12 320) graduates, Lithuania - 133759 students and 29683 graduates, totalling at 269133 students and 55741 graduates. Meanwhile, Finland had 297163 students, i.e., 10.4\% (excl. ISCED 5 $17 \%$ ) more than Baltic States and 56066 graduates i.e. $0.6 \%$ (excl. ISCED $5-7.3 \%$ ) more than Baltics. The fact that the actual number of enrolled students and graduates is higher in Finland than in Baltics 


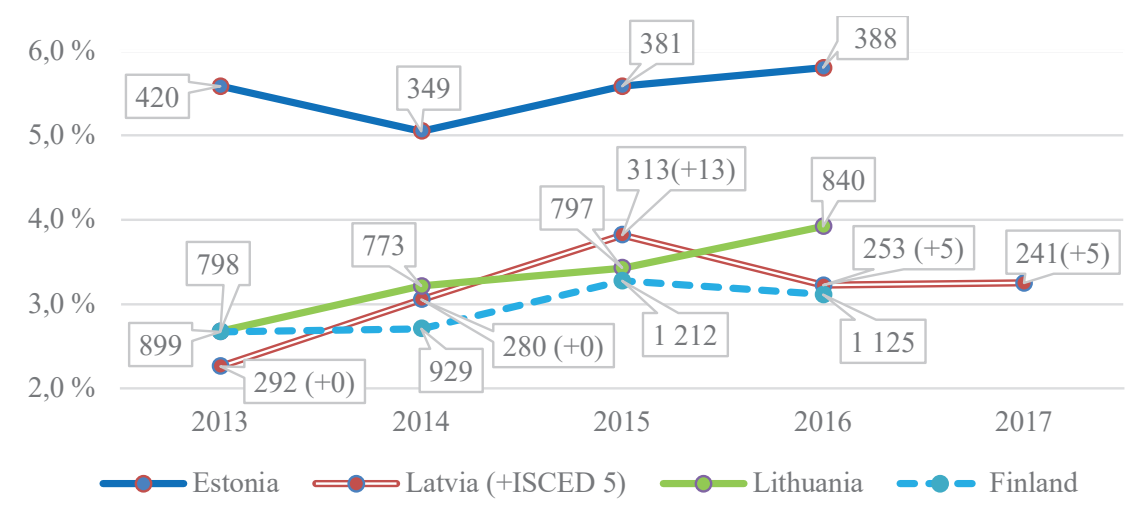

Figure 1. Share of Natural sciences, mathematics and statistics field among ISCED 6 graduates (\%), number of graduates (source: author based on Eurostat, 2019).

despite falling behind in the population indicators (as described before) can be explained by Finland's extensive education export to foreign citizens.

When comparing Lithuania, Latvia, Estonia and Finland according to the divisions per study field, differences can be observed (Table 2). In terms of enrolled students in STEM fields (ISCED 5-8) from 2013 to 2017, Finland is leading with a combined median value of $33.9 \%$, followed by Estonia (30.9\%), Lithuania $(24.8 \%)$ and Latvia $(24.0 \%)$. In the $5^{\text {th }}$ Natural sciences field the Baltic States have had a relative increase - in Latvia from 2.2\% (2 051 students) to $2.8 \%$ (2 283), numerical increase (nom. inc.) of $11.3 \%$; in Lithuania from $3.4 \%$ (5 352) to $3.6 \%$ (4 765), numerical decrease (num.decr.) of $-11.0 \%$, in Estonia from $5.1 \%$ (3 320) to 6.1 (2 929), num.decr. -11.8\%; while Finland has had a relative downward trend from $5.8 \%$ (17 941) to $5.7 \%$ (16 669), num.decr. $-7.1 \%$. In $6^{\text {th }}$ ICT field: Latvia had a relative increase from $4.6 \%$ (4 353) to $6.2 \%$ (5 172), nom.inc. 18.8\%; in Lithuania - from 2.2\% (3 510) to 4.1\% (5 156), nom.inc. 46.9\%; in Estonia - from 7.6\% (4 940) to $8.0 \%$ (4 155), num.decr. $-15.9 \%$; while in Finland - from 5.8\% (28 469) to 5.6\% (27 042), num. decr. $-5.0 \%$. In the $7^{\text {th }}$ Engineering field Latvia and Lithuania have witnessed a relative increase: in Latvia
- from $15.6 \%$ (14 744) to $16.6 \%$ (13 742), num.decr. $-6.8 \%$; in Lithuania - from $18.0 \%$ (28 773) to $18.3 \%$ (24 439), num.decr. 15.1\%; while in Estonia - from $16.8 \%$ (10 867) to $16.8 \%$ (7 794), num.decr. $-28.3 \%$; and in Finland - from 19.2\% (59 239) to $19.1 \%(55$ 959), num. decr. $-5.5 \%$.

Both relative and numerical increase in the number of students in the $5^{\text {th }}$ Natural sciences field was seen only in Latvia, in $6^{\text {th }}$ ICT field - in Latvia and Lithuania, in the $7^{\text {th }}$ Engineering field no country experienced dual increase, while only Latvia and Lithuania had a relative increase. It should be noted that over the period from 2013 to 2017 only Latvia has managed to increase both relative and numerical results in more than one $\left(5^{\text {th }}\right.$ and $\left.6^{\text {th }}\right)$ STEM field, while Lithuania had made remarkable results in the $6^{\text {th }}$ field - a numerical increase of $46.9 \%$; however, it should be noted that in this case the threshold was specifically low - only $2.7 \%$ in a relative share. Estonia and Finland had experienced numerical decrease in all three STEM fields, despite relative increase for Estonia in $5^{\text {th }}$ and $6^{\text {th }}$ study field.

When analysing the changes in terms of graduates (grad.) (Figure 1) in the $5^{\text {th }}$ Natural sciences field in 2016: Estonia is leading with the highest share $(5.8 \%$, 388 grad.), followed by Lithuania (3.9\%, $840 \mathrm{grad}$.$) ,$

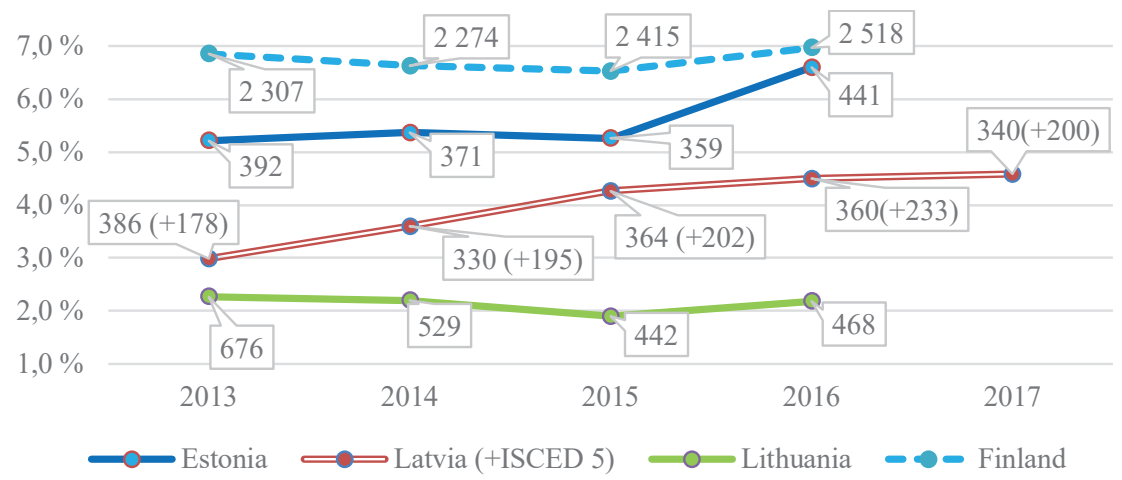

Figure 2. Share of Information and Communication Technologies field among ISCED 6 (+ ISCED 5) graduates (\%), number of graduates (source: author based on Eurostat, 2019; OECD, 2017a). 


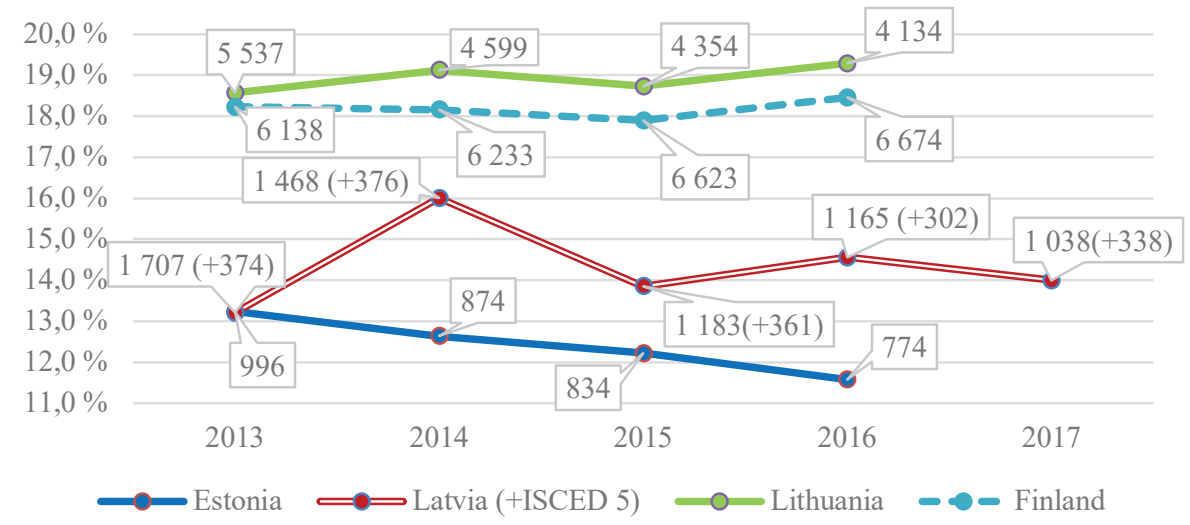

Figure 3. Share of Engineering, manufacturing and construction field among ISCED 6 students (\%), number of students (source: author based on Eurostat, 2019, OECD, 2017a).

Latvia (3.1\%, 258 grad.), and Finland (3.1\%, 1125 grad.). Combined numerical value in the Baltic States -1978 graduates which is by $75.8 \%$ higher than that of Finland.

In the $6^{\text {th }}$ the ICT field (Figure 2) in 2016: Finland was leading with the highest share of graduates per field (7.0\%, 2518 graduates), followed by Estonia (6.6\%, 441 grad.), Latvia (4.5\%, 593 grad.), and Lithuania $(2.2 \%, 469$ grad.). It can be seen that over the period the output number has only increased in Finland (from 2307 to 2518 graduates) and Estonia (from 392 to 441 grad.). In the case of Latvia, a decrease in the numerical value - from 564 (2013) to 540 (2017) ICT graduates can be seen, while correspondingly only 386 and 340 were bachelor graduates, while the rest were short-cycle tertiary graduates. In 2016, the Baltic States' combined result value was 1796 graduates, which is by $40.2 \%$ lower than that of Finland.

In the $7^{\text {th }}$ Engineering field (Figure 3) in 2016: Lithuania is the leader with the highest share (19.3\%, 4 134 grad.), followed by Finland (18.5\%, 6674 grad.), Latvia (14.6\%, 1467 grad.), and Estonia (11.6\%, 774 grad.). The combined number of graduates the Baltic States total 7755 graduates, which is by $16.2 \%$ higher than that of Finland.

According to a skills forecast by 'Danish Technological Institute' (EC, 2015) for the period 2013 to 2025, the demand for STEM professionals (both for expansion and replacement demand) in industry would be the following: Estonia - 19 400, Latvia - 74 140, Lithuania - 22 290, in Finland 109780 professionals and associated professionals. The total supply of STEM professionals in the given countries reached the following: in Estonia - 11234 graduates or $57.9 \%$ of the projected demand, in Latvia - 17582 (23.7\%), in Lithuania - 31572 (141\%), and in Finland $-78176(71.2 \%)$. Thereby Lithuania and Finland are in a better situation, with Estonia catching up, while Latvia is struggling to meet the labour market demands.

\section{Structural reforms in HEIs}

In Latvia concerns exist about the fragmentation of tertiary study programmes whose number despite the decrease of student population (by $38 \%$ between 2005 and 2017) have increased by a third (EC, 2018). Structural reforms to optimise the higher education institution network are missing. In order to strengthen the quality assurance, career tracking was introduced in 2018 (EC, 2018). In order to promote STEM, the share of publicly financed study places was increased in STEM fields (EC, 2018), thus increasing share of enrolled students (Table 2). The share of foreign nationals studying in Latvia reached $5.5 \%$ in 2017 (Eurostat, 2019). In Estonia, there is a deficit of STEM graduates - only 12.8 per 1000 people (20-29 year olds) compared to 19.1 (EU-28 average). Their skillsset is insufficiently aligned to labour market needs (EC, 2018). In the ICT field, despite the latest increase in the number of ICT graduates, the unmet demand in the industry remains explicitly high (EC, 2018). As noted by the Education, Audiovisual and Culture Executive Agency (EACEA) over the period Estonia has introduced changes to the Higher Education Act which included new quality requirements and has increased doctoral grants (EACEA, 2019). No significant mergers of universities have taken place in the period of 5 years. The share of foreign nationals studying in Estonia reached 6.8\% in 2016 (Eurostat, 2019). In Lithuania, the EU leader in terms of tertiary educational attendance of people aged 3034, the total number of students from 2012 until 2017 has fallen by $36.8 \%$. There are concerns about the higher education system's efficiency and quality. In order to tackle these challenges, Lithuania launched a series of reforms to consolidate the network of universities and strengthen the accreditation system (EC, 2018). In 2018, the Lithuanian Parliament passed two resolutions: on the consolidation of five state universities in Kaunas into two, and on merging the Šiauliai University ( $\breve{S} U$ ) with Vilnius University 
(VU) (EACEA, 2019). In order to improve the study quality, Lithuania has joined the 'Eurograduate' pilot, which is testing the possibility to introduce a Europe-wide graduate tracking system (EC, 2018). In 2016 , only $2.6 \%$ of graduates in Lithuania were from abroad (Eurostat, 2019). In Finland, in 2018 as a result of a merger between the University of Tampere and Tampere University of Technology the second largest university in Finland by number of students was established (the second of only two private universities in Finland) - Tampere University (UWN, 2019). In terms of study quality, career tracking (started in 2004) was extended to all public universities in 2016 (EC, 2018) thus creating a space for synergy in-between the technology and social sciences, which is a future prerequisite for development of Industry 4.0 In 2018, a proposal was submitted for amendments to the higher education law to ensure easier access to higher education and enable the provision of modules as continuous professional development (EACEA, 2019). The share of foreign nationals studying in Finland reached 7.7\% in 2017, down from 8.1 in 2016 (Eurostat, 2019).

\section{Conclusions}

1. In 2018, the combined population of Baltic States reached 6062413 people, which is by $10 \%$ more than that of Finland with 5513130 people. Among the young adults' (aged 18 to 34 years) cohort Baltic States surpassed with 1277711 young adults, i.e. $10.7 \%$ more than that of Finland (1 154564 young persons). Thereby in terms of population the Baltic States has a numerical advantage over Finland.

2. On an ISCED 5-8 scale Finland had 269133 enrolled students (17\% more) and 56066 graduates $(0.6 \%$ more) than the Baltic States combined - 253940 students and 52265 graduates accordingly. The actual number of enrolled students and graduates is higher in Finland despite lagging behind in terms of share of population with higher education among young adults (age group 25-34 years) which could be explained by Finland's extensive education export to foreign citizens who do not settle in the country after graduation.

3. In terms of number of students enrolled in STEM fields (ISCED 5-8) in the period from 2013 to 2017, Finland was leading with a combined median value of $33.9 \%$, followed by Estonia (30.9\%), Lithuania (24.8\%) and Latvia (24.0\%).

4. In 2016 in terms of number of graduates in STEM study fields, the results of Baltic States combined were greater than those of Finland in the $5^{\text {th }}$ Natural sciences field (by $75.8 \%$ ) and in the $7^{\text {th }}$ Engineering field (by 16.2\%). Meanwhile, Finland had an upper hand over the Baltic States combined in the $6^{\text {th }}$ ICT study field (by $40.2 \%$ ).
5. Over the period 2013 to 2017 in terms of the number of students enrolled in the $5^{\text {th }}$ Natural sciences field, only Latvia had both relative and numerical increase, Lithuania and Estonia - a relative increase and numerical decrease, Finland - both relative and numerical decrease. In the $6^{\text {th }}$ ICT field Latvia and Lithuania both had a relative and numerical increase, Estonia - only a relative increase with numerical decrease, Finland - a relative and numerical decrease. In the $7^{\text {th }}$ Engineering field both Latvia and Lithuania experienced only a relative increase with a numerical decrease, while Estonia and Finland both experienced a relative and numerical decrease.

6. Overall, in the period from 2013 to 2017, in terms of students studying in HEIs, only Latvia managed to increase both relative and numerical results in more than one $\left(5^{\text {th }}\right.$ and $\left.6^{\text {th }}\right)$ STEM field, Lithuania made a remarkable result in one STEM $\left(6^{\text {th }}\right)$ field by staggering $46.9 \%$. This achievement however can be explained by the specifically low start margin $-2.7 \%$ relative share in 2013 . Estonia (despite a relative increase in $5^{\text {th }}$ and $6^{\text {th }}$ study field) and Finland experienced numerical decrease in all three STEM fields.

7. The advances in computer technologies and machine learning capabilities have increased the demand for STEM capable professionals. In terms of Industry 4.0 ready professionals, currently Finland has a technological advantage in ICT field over the Baltic States. The merger of University of Tampere and Tampere University of Technology is an example of creation of environment for synergy in-between the technological and social sciences, which is a future prerequisite for the development of Industry 4.0

8. In terms of the total supply of STEM professionals, in 2017 Lithuania was a leader with $141 \%$ of the projected demand, followed by Finland (71.2\%), Estonia (57.9\%) and Latvia (only 23.7\%). The mediocre results in Latvia indicate a sustained deficit of STEM professionals and further struggles to meet the labour market demands in the midterm and long-term.

9. The research on enrolled students and graduates in STEM fields show that the Baltic States and Finland have both similar and different tendencies as well as different strategies for pursuing improvements in higher education to increase the number of students in STEM related study fields. In terms of a further research, it would be beneficial to carry out an in-depth statistical study on the factors (public spending on higher education, higher education policy, structural changes to university network, activities for promotion of STEM studies, etc.) 
which may had an influence on the STEM study process trends as well as on enrolment all of the observed countries.

\section{Acknowledgements}

The research is supported by the National research programme project INTERFRAME-LV.

\section{References}

1. CEDEFOP. (2016). Skill Shortage and Surplus Occupations in Europe. ISSN 1831-2411. pp. 2. Retrieved February 5, 2019, from http://www.cedefop.europa.eu/files/9115_en.pdf.

2. EACEA. (2019). National Policies Platform. Eurydice. Retrieved January 20, 2019, from https://eacea. ec.europa.eu/national-policies/eurydice/content/national-reforms-higher-education-38 en Access.

3. EC. (2015). Does the EU need more STEM graduates? Final Report. Retrieved January 25, 2019, from http://www.cedefop.europa.eu/files/9115 en.pdf.

4. EC. (2018). Education and Training Monitor 2018. Country analysis. Retrieved January 10, 2019, from https://ec.europa.eu/education/sites/education/files/document-library-docs/volume-2-2018-educationand-training-monitor-country-analysis.pdf.

5. European Union. (2017). Digitising European Industry: Working Group 2 - Digital Industrial Platforms 1. Retrieved January 25, 2019, from https://ec.europa.eu/futurium/en/system/files/ged/dei_wg2_final_report.pdf.

6. Eurostat. (2018). Population on 1 January by age and sex (demo_pjan). 1. Retrieved January 15, 2019, from http://www.cedefop.europa.eu/files/9115_en.pdf.

7. Eurostat. (2019). Tertiary education statistics. [educ_uoe_grad01] [educ_uoe_mobg02] Retrieved February 10, 2019, from https://ec.europa.eu/eurostat/web/education-and-training/data/database.

8. Foresight. (2013). The future of manufacturing: A new era of opportunity and challenge for the UK: Summary Report, The Government Office for Science, London. Retrieved January 15, 2019, from https:// assets.publishing.service.gov.uk/government/uploads/system/uploads/attachment_data/file/255923/13810-future-manufacturing-summary-report.pdf.

9. Goldstein, H. (2010). The 'Entrepreneurial Turn' and Regional Economic Development. Mission of Universities. Annals of Regional Science, Vol. 44, (1), pp. 83-109. DOI: 10.1007/s00168-008-0241-z.

10. Goldstein, H., \& Rehbogen, A. (2013). University Engagement and Knowledge Commercialization: an Analysis of Faculty Attitudes, Knowledge Commercialization and Valorization in Regional Economic Development, pp. 61-84.

11. BMBF (2011). Bericht der Bundesregierung Zukunftsprojekte der Hightech-Strategie (HTS-Aktionsplan) Retrieved January 28, 2019, from https://www.iwbio.de/fileadmin/Publikationen/IWBio-Publikationen/ HTS-Aktionsplan.pdf.

12. Knight, J. (2012). A Conceptual Framework for the Regionalization of Higher Education: Application to Asia, in Higher Education Regionalization in Asia Pacific. Implications for Governance, Citizenship and University Transformation, (ed.). John N. Hawkins, Ka Ho Mok, Deane E. Neubauer. London: Palgrave Macmillan, p. 215. DOI: 10.1057/9781137311801.

13. OECD. (2017a). Population with tertiary education $25-34$ year-olds $/ 55-64$ year-olds, $\%$ in same age group, 2017 Retrieved January 27, 2019, from https://www.oecd-ilibrary.org/education/population-with-tertiaryeducation/indicator/english $0 \mathrm{~b} 8 \mathrm{f} 90 \mathrm{e} 9$-en.

14. OECD. (2017b). OECD Reviews of Innovation Policy: Finland 2017. ISBN 978-92-64-27636-9.

15. OECD. (2017c). Education at a Glance 2017: OECD Indicators. Indicator A1. To What Level have Adults Studied. Retrieved January 28, 2019, from https:/www.oecd-ilibrary.org/docserver/eag-2017-7-en.pdf.

16. Radinger-Peer, V., \& Pflitsch, G. (2017). The role of higher education institutions in regional transition paths towards sustainability. Review of Regional Research, Vol. 37(2), pp. 161-187. DOI: 10.1007/s10037017-0116-9.

17. UNESCO. (2015). International Standard Classification of Education. Fields of education and training 2013 (ISCED-F 2013) - Detailed field descriptions. Retrieved February 5, 2019, from http://uis.unesco. $\mathrm{org} / \mathrm{sites} /$ default/files/documents/international-standard-classification-of-education-fields-of-educationand-training-2013-detailed-field-descriptions-2015-en.pdf.

18. UWN. (2019). Merger makes Tampere the second-largest university. Retrieved January 3, 2019, from https://www.universityworldnews.com/post.php?story=2019011013130145. 